\title{
CURRICULUM PREPARATION TRAINING INDEPENDENT CAMPUS, FREEDOM TO LEARN (MBKM) IN STUDY PROGRAMS AS AN EFFORT TO MEET THE MAIN PERFORMANCE INDICATORS OF HIGHER EDUCATION
}

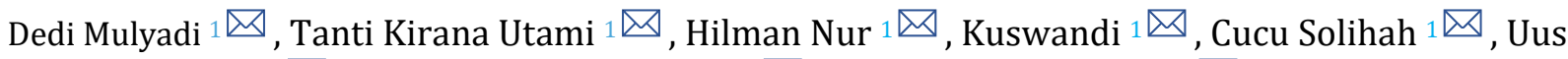

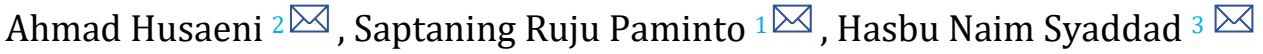 \\ ${ }^{1}$ Faculty of Law, Universitas Suryakancana, Indonesia. \\ ${ }^{2}$ Department of Islamic Economics, Faculty of Islamic Economics and Business, Universitas Suryakancana. \\ Indonesia. \\ ${ }^{3}$ Department of Informatics Engineering, Faculty of Engineering, Universitas Suryakancana. Indonesia.
}

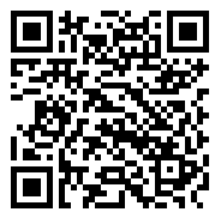

\section{ABSTRACT}

Received 1 November 2021

Accepted 12 December 2021

Published 31 December 2021

CorrespondingAuthor

Tanti Kirana Utami,

tantikiranautami@unsur.ac.id

DOI

10.29121/granthaalayah.v9.i12.2021 .4430

Funding: This research received no specific grant from any funding agency in the public, commercial, or not-for-profit sectors.

Copyright: (C) 2021 The Author(s). This is an open access article distributed under the terms of the Creative Commons Attribution License, which permits unrestricted use, distribution, and reproduction in any medium, provided the original author and source are credited.

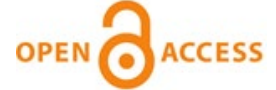

The MBKM policy provides opportunities for students to gain more comprehensive learning experiences and new competencies through several learning activities. Service activities are carried out by holding two types of activities, namely the socialization of MBKM policies and workshops on preparing the MBKM curriculum. The target of this activity is the leadership of the study program, lecturers, and education staff; with this activity, the participants become more familiar with preparing the curriculum, starting from making learning outcomes to assessment techniques. Furthermore, the impact of this training realizes the fulfillment of higher education performance indicators.

Keywords: Main Performance Indicators, Curriculum, MBKM

\section{INTRODUCTION}

The higher education curriculum is a program to produce graduates having qualifications equivalent to the qualifications agreed in the IQF. Based on Law Number 12 of 2012 concerning Higher Education, it is stated that curriculum preparation is the right of universities. Still, it is said that it must refer to national standards (Article 35 paragraph (1)). The curriculum, as a design, consists of four elements, namely learning outcomes, study materials, learning processes to achieve, and assessment (Directorate General of Learning and Student Affairs, 2018).

The MBKM curriculum is one of the Minister of Education and Culture policies, Nadiem Makariem. One of the MBKM policy programs is the Right to Learn 3 (Three) Semesters Outside the Study Program. The program mandates various regulations or legal foundations for higher education to improve the quality of learning and higher education graduates. Multiple forms of learning activities outside of Higher Education. All of the above activities must be carried out with the guidance of the Lecturer. Independent campuses are expected to provide contextual field experiences to improve student competence, prepare to work, or create new job opportunities. 
The MBKM policy launched by the Ministry of Education and Culture continues to be a concern for universities. Informing a curriculum, many things must be considered in it. Not only courses but also the process of implementing the curriculum until it can finally be applied to all students. MBKM itself is a new program launched by the Indonesian Ministry of Education and Culture. This program is expected to bring a unique atmosphere for students in Indonesia to be more prepared and alert when they graduate from a university.

To realize the ideals of higher education, changes must be made in the evaluation of higher education performance which will be assessed based on the Main Performance Indicators. The Main Performance Indicators issued by the Minister of Education and Culture through the Decree of the Minister of Education and Culture Number 754/P/2020 are new performance measures for higher education institutions to realize adaptive higher education based on more concrete outputs. The policy is also a measuring tool to accelerate the implementation of the Independent Learning-Independent Campus. Decree of the Minister of Education and Culture Number $754 / \mathrm{P} / 2020$ as amended by Decree of the Minister of Education and Culture Number 3/M/2021.

Learning on an Independent Campus provides challenges and opportunities for the development of innovation, creativity, capacity, personality, and student needs, as well as developing independence in seeking and finding knowledge through realities and field dynamics such as ability requirements, real problems, social interaction, collaboration, self-management, demands performance, targets, and achievements. Students ' hard and soft skills will be formed strongly through the Freedom to Learn program that is well designed and implemented.

Universitas Suryakancana (UNSUR) responded positively to the MBKM policy. To support the success of the MBKM policy, UNSUR seeks to facilitate the implementation of the fulfillment and learning rights of students by making policies for the performance of the MBKM program, namely by making the Rector's Decree No. 31/SK/REK/UNSUR/IX/2020 concerning Guidelines for the Implementation of the Suryakancana University MBKM Curriculum. Based on the description above, the author will conduct research related to implementing the MBKM curriculum at Universitas Suryakancana and the impact of the MBKM curriculum on the implementation of the Main Performance Indicators. Some educators have realized that learning sees students as intelligent, critical, and creative and can work together to solve problems related to everyday life Djoko Apriono (2013).

Freedom means choosing alternative policies between continuing the existing study program curriculum design or offering new curriculum designs that provide innovation and unique experiences for students. The implementation of MBKM itself is based on the demands of the development of knowledge, competencies, and skills of the 21st century, to the importance of changes in lecture activities.

Following the regulations, MBKM is carried out by preparing a curriculum for learning recognition or independent student activities. Freedom of learning or activities will be arranged following the learning outcomes promised. Regarding this policy, Minister of Education Regulations No. 3 of 2020 states that universities are obliged to give students the right to voluntarily (can be taken or not), in the form of providing opportunities to take part in activities outside of tertiary institutions, plus one-semester lecture activities outside the study program on the same campus.

The MBKM policy provides opportunities for students to gain more comprehensive learning experiences and new competencies through several learning activities. In addition, students are also given the freedom to participate in learning activities outside their study program in the same university with a 
particular credit weight. Students can carry out all these activities with the guidance of lecturers. The implementation of MBKM in Higher Education only starts with two major activities: first, providing 20 credits of lectures outside study programs that are still in one institution, and second, providing programs or activities equivalent to 40 credits.

Based on the description above, the holding of MBKM policy socialization and training on the preparation of the MBKM curriculum positively impacted the readiness of study programs in implementing MBKM and meeting the Key Performance Indicators.

\section{METHOD}

The method used is through socialization to study programs that have not implemented MBKM in the following ways: a) Phase I Field Observation; b) Phase II Licensing Activities, the Service Team requests permission from the Chancellor regarding socialization activities and assistance in the preparation of the MBKM curriculum to be implemented; c) Phase III Socialization Activities, Activities are carried out with the face-to-face method and still pay attention to health protocols, use masks, apply the habit of washing hands with the use of hand sanitizers, and limiting distance. The activities carried out by the team are carried out at UNSUR.

\section{RESULTS AND DISCUSSIONS}

Law Number 12 of 2012 Article 35 paragraph (2) mandates that the Higher Education Curriculum be developed by each Tertiary Education Institution concerning the National Higher Education Standards for each Study Program, which includes developing intellectual intelligence, noble character, and skills. The National Standard for Higher Education (SN-Dikti), as regulated in Permendikbud Number 3 of 2020 Article 1, states that the curriculum is a set of plans and arrangements regarding the objectives, content, and learning materials as well as the methods used as guidelines for the implementation of learning activities to achieve educational goals. Tall. The Higher Education Curriculum is an institutional mandate that must constantly be updated following the development needs and science and technology as outlined in the Learning Outcomes. Universities as producers of academic human resources need to measure their graduates, whether the graduates produced have the 'ability' equivalent to the 'ability' (learning achievement) that has been formulated in the IQF qualification level. To increase the link and match between higher education graduates and the business and industrial world as well as a rapidly changing future, in early 2020, the Ministry of Education and Culture introduced a new policy in the field of higher education through the MBK program Aris Junaidi et al. (2020) .

Education aims to print an intelligent generation and has a virtuous character. Not only that, but education also encourages change for the better from age to generation. Through education, it is hoped that it can give birth to innovative, creative things and produce a generation that can bring good change Dela Khoirul (2020).

The Ministry of Education and Culture has encouraged universities to develop activity programs oriented towards the achievement of Key Performance Indicators, including the performance of Higher Education in implementing MBKM. The key to the successful implementation of the MBKM policy in a university lies in the courage to change the mindset from a rigid content-based curriculum approach to a curriculum based on adaptive and flexible learning outcomes, preparing students to 
become adults who are capable of being independent in line with the demands of the global community.

Several steps need to be considered in preparing the MBKM curriculum, namely: first, each university appoints a curriculum development team to design technical guidelines and guidelines for implementing MBKM policies, especially regarding rules, ethics, procedures, implementation mechanisms, systems to be used, and choices developed program. Second, every higher education institution needs to conduct socialization and assessments with parties who are partners in activities, including schools/madrasahs, industry, banking, other universities, and other parties who are still related to the MBKM program; and third, the study program identifies, classifies courses that have conformity (recognition) with the MBKM program that is the student's choice. Through changes to the MBKM-based Higher Education curriculum policy, it is hoped that all graduates of the study program can answer the challenges and problems in the global community.

According to Nadiem Anwar Makarim, what makes him innovative is his way of thinking. This change aims to produce graduates who can survive, adapt, and have non-technical abilities to live and work in society. Graduates need capital for their lives in the future, not just in their present life. The profile of graduates in the Indonesian education roadmap includes six profiles, including 1) spiritual integrity, 2) diversity-minded, 3) independent, 4) cooperation, 5) critical reasoning, and 6) creative. Higher education must encourage people not only in what field, but also these people have the ability and willingness to continue learning for life following the acceleration of economic change, are adaptive, collaborative, creative, and openminded.

The curriculum is a set of plans and arrangements regarding the objectives, content, and learning materials. The methods are used as guidelines for implementing learning activities to achieve the goals of Higher Education Susetyo (2020) . Implementing the MBKM curriculum at Suryakancana University provides many benefits for lecturers, students, and partners, namely lecturers and students can carry out activities outside the campus that provide a lot of experience in nonacademic academic fields especially realizing collaborative learning. Collaborative learning offers a lot of added value, both for students and lecturers.

MBKM is an advanced design of applying the study program curriculum based on the Indonesian National Qualifications Framework, oriented towards the integrity of learning competency achievement, including elements of attitudes or values, knowledge, general skills, and special skills. Of course, the main principle in the IQF is not how many classes are offered but how much competence appears in the studies (Fuzan, 2021).

Study programs are challenged in developing an adaptive curriculum and adapting to the increasingly rapid developments of the times without leaving the goal of producing graduates following predetermined learning outcomes. In addition, the implementation of the MBKM policy requires collaboration and cooperation with partners or other parties related to their scientific fields and participating in supporting the desired learning outcomes. The curriculum is a set of plans and arrangements regarding the objectives, content, and learning materials, as well as the methods used as guidelines for the implementation of learning activities to achieve the goals of Higher Education (Minister of Education and Culture Regulation No. 3 of 2020 concerning National Standards for Higher Education). Curriculum preparation should be based on a solid foundation, both philosophically, sociologically, psychologically, historically, as well as juridically. 
Indonesia as a state of law. This statement indicates that all actions must be based on the law Hermawan (2014). According to Henny Nuraeny and Tanti Kirana Utami (2015), Indonesia as a legal state is stated in Article 1 paragraph (3) of the third amendment to the 1945 Constitution of the Republic of Indonesia, which states that Indonesia adheres to the principle and the concept of Pancasila can be maintained in the Preamble to 1945 Constitution. The following are some legal foundations that need to be referred to in the preparation and implementation of the curriculum:

1) Law of the Republic of Indonesia Number 14 of 2005 concerning Teachers and Lecturers (State Gazette of the Republic of Indonesia of 2005 Number 157, Supplement to the State Gazette of the Republic of Indonesia Number 4586).

2) Law of the Republic of Indonesia Number 12 of 2012 concerning Higher Education (State Gazette of the Republic of Indonesia of 2012 Number 158, Supplement to the State Gazette of the Republic of Indonesia Number 5336).

3) Presidential Regulation of the Republic of Indonesia Number 8 of 2012, concerning the Indonesian National Qualifications Framework (KKNI).

4) Regulation of the Minister of Education and Culture of the Republic of Indonesia Number 73 of 2013, concerning the Implementation of the KKNI in the Higher Education Sector.

5) Regulation of the Minister of Research, Technology and Higher Education of the Republic of Indonesia Number 62 of 2016 concerning the Higher Education Quality Assurance System.

6) Regulation of the Minister of Research, Technology and Higher Education Number 59 of 2018, concerning Diplomas, Certificates of Competence, Professional Certificates, Degrees, and Procedures for Writing Degrees in Higher Education.

7) Decree of the Minister of Research, Technology and Higher Education No. 123 of 2019 concerning Internships and Recognition of Industrial Internship Semester Credit Units for Applied Undergraduate and Undergraduate Programs.

8) Minister of Education and Culture Regulation No. 3 of 2020, concerning the National Standards for Higher Education.

9) Minister of Education and Culture Regulation No. 5 of 2020, concerning Accreditation of Study Programs and Universities.

10) Minister of Education and Culture Regulation No. 7 of 2020 concerning the Establishment of Changes, the Dissolution of State Universities, and the Establishment, Amendment, Revocation of Permits for Private Universities.

11) Minister of Education and Culture Regulation No. 22 of 2020, regarding the Strategic Plan of the Ministry of Education and Culture.

Laws in Indonesia are known as statutory regulations that provide a general basis or guideline for how people interact in state life within the corridors of the legal framework that has been provided for by the Constitution. In carrying out its role, the Act is an arrangement that contains matters that are only of a principle and general nature. This results in the need for other technical legislation Fitriani Ahlan (2017).

The flow of how the curriculum for applied undergraduate and undergraduate study programs implements MBKM. According to the KKNI grading, applied bachelors/bachelors are educational programs at level 6. Graduate competency standards, content standards, process standards, and standards. Evaluation of level 6 is regulated in SN-Dikti. Graduate Competency Standards formulated as Graduate Learning Outcomes include General Attitudes and Skills CPL (in the SN-Dikti 
Appendix). At the same time, Specific Knowledge and Skills CPL is agreed upon by associations/forums managing similar study programs.

The formulation of CPL is also based on the results of the evaluation of the curriculum of the study program through measuring the achievement of the current curriculum CPL, tracer studies, input from users of graduates, alumni, and experts in their fields. Curriculum evaluation also examines the development of science and technology in relevant areas, the needs of the job market, and the vision and values developed by each institution.

The service activities are described below: Curriculum Assistance Program in 10 (ten) Suryakancana University Study Programs, where the study program has not implemented the MBKM Curriculum intending to know various problems in aggregating the understanding of MBKM curriculum implementation in the study program, with the mentoring process as follows:

1) Mentoring I will be carried out on Thursday, December 16, 2021, from 9.00 to 12.00 WIB. The number of study programs that participated in this curriculum mentoring activity consisted of Faculty of Engineering, Faculty of Economics and Islamic Business, which was followed by 21 people, which involved the Head of Study Program, Secretary of Study Program, Lecturers, Students, Academic Staff

2) Mentoring II is carried out on Friday, December 17, 2021, from 9.00 to 1100 wib. The number of study programs participating in this curriculum mentoring activity consisted of the Faculty of Teacher Training and Education, the Faculty of Applied Science which involved the Head of Study Programs, the Secretary of Study Programs, Lecturers, Students, and Academic Staff.

3) Curriculum assistance is intended to encourage and facilitate Study Programs at Suryakancana University, which are trying hard to implement the MBKM curriculum in their learning process.

4) The discussion begins with the history, legal basis, development of the MBKM curriculum at the Faculty of Law and various policies as instruments for implementing the MBKM curriculum, responses to the implementation of the MBKM curriculum from Staff, Lecturers, Leaders, and Students, as well as various problems as a reaction to the performance of the MBKM curriculum at the Faculty Law.

The MBKM curriculum preparation training is carried out in stages; first, a general explanation of the MBKM policy, then a description of the preparation of the MBKM curriculum. The discussion is conducted through interactive discussions between the presenters and the training participants. Discussion of the material focused on:

1) How is the curriculum change process?

2) How to integrate existing programs.

3) Curriculum change and assessment models.

4) MBKM program budget model.

5) Implementation of the curriculum starting from Registration, Mid-Semester Examination, Final Semester Examination, and incentives for MBKM students to boost MBKM enthusiasts in the faculty.

6) The principle of the MBKM curriculum model for Physical Education, Health and Recreation, then make changes to the curriculum in SM-V collaboration between faculties of one university.

7) Changes in the curriculum in SM-VI cooperation between universities for student exchange programs between universities.

8) Curriculum changes in SM-VII Teaching assistance. 
9) Transcript for MBKM is only one after accumulated.

10) Flexible Curriculum.

11) Curriculum changes directly 20 credits (can / cannot)

For UNSUR students, the MKBM program is indeed very beneficial, including increasing competence and new experiences according to their needs. The number of distributions of selected courses is much simpler because certain subjects may no longer be taught because they have changed; MBKM activities recognize them. The eight MBKM programs offered can bring about change for students and lecturers in a more independent pattern of activities, still within the framework of strengthening students' competence.

The stages of preparing curriculum documents are divided into three phases: curriculum design, learning design, and evaluation of learning programs. The important thing that needs to be considered in developing, implementing, evaluating a curriculum based on SN-Dikti is that it is stated that SKL/CPL is the primary reference or foundation. Thus, the Higher Education Curriculum developed based on the SN-Dikti has used the Outcome-Based Education (OBE) approach. Various models of OBE approaches or paradigms are used in curriculum development and implementation, of which the simplest consists of three interacting stages, which are as follows:

1) Outcome Based Curriculum (OBC), curriculum development based on the profile and Graduate Learning Outcomes (CPL). Based on this CPL, the study materials (body of knowledge) are derived, the formation of courses and the weights of the credits, curriculum maps, learning designs expressed in the form of Semester Learning Plans (RPS), developing teaching materials, and developing assessment and evaluation instruments.

2) Outcome Based Learning and Teaching (OBLT), the implementation of learning activities which are defined as interactions in learning activities between lecturers, students, and learning resources.

3) Outcome-Based Assessment and Evaluation (OBAE), an assessment and evaluation approach carried out on the achievement of CPL to improve the quality of continuous learning. Assessment is carried out on the learning process and on the results of achieving CPL. Likewise, curriculum evaluation is carried out on the achievement of the Study Program CPL, and the results are used for continuous improvement.

\section{CONCLUSIONS}

The MBKM curriculum is a curriculum that provides opportunities for students to study outside the campus either in other faculties or through nine choices of MBKM learning activities provided by the government. Implementation of MBKM policy socialization and MBKM curriculum preparation training had a positive impact on the readiness of study programs in implementing MBKM and meeting Key Performance Indicators. Universities are currently being encouraged to contribute more significantly to economic development and community progress through various innovations that have a real impact, both through research programs and community service.

\section{ACKNOWLADGEMENTS}

The authors would like to thank the Secretariat of the Directorate General of Higher Education, Research and Technology of the Directorate General of Higher Education, Research and Technology of the Ministry of Education and Culture 
Research and Technology of the Republic of Indonesia, which has provided funding for the implementation of this research through the Funding Assistance Program for the Independent Learning Policy Research Program. Independent Campus and Community Service Based on Research Results and Prototypes of Private Universities in 2021.

\section{REFERENCES}

Aris Junaidi et.al, (2020) Panduan Penyusunan Kurikulum Pendidikan Tinggi Di Era Industri 4.0 Untuk Mendukung Merdeka Belajar-Kampus Merdeka, Dirjen Dikti Kemendikbud,

Atang Hermawan Usman, (2014) Kesadaran Hukum Masyarakat dan Pemerintah Sebagai Faktor Tegaknya Negara Hukum di Indonesia, Jurnal Wawasan Hukum, Vol. 30 No. 1 Februari. Retrieved from http://ejournal.sthb.ac.id/index.php/jwy/article/view/74

Dela Khoirul Ainia, (2020) Merdeka Belajar dalam Pandangan Ki Hadjar Dewantara dan Relevansinya bagi Pengembangan Pendidikan Karakter, Jurnal Filsafat Indonesia, Vol 3 No 3 Tahun. Retrieved from https://ejournal.undiksha.ac.id/index.php/JFI/article/view/24525

Direktorat Jenderal Pembelajaran dan Kemahasiswaan, (2018) Buku Panduan Penyusunan Kurikulum Pendidikan Tinggi,

Djoko Apriono, (2013) Pembelajaran Kolaboratif: Suatu Landasan untuk Membangun Kebersamaan dan Keterampilan Kerjasama, Diklus, Edisi XVII, Nomor $01, \quad$ September. Retrieved from https://journal.uny.ac.id/index.php/diklus/article/view/2897

Fauzan, (2021) Kesiapan Perguruan Tinggi dalam Penerapan Kebijakan Merdeka Belajar Kampus Merdeka, https://fitk.uinjkt.ac.id/kesiapan-perguruantinggi-dalam-penerapan-kebijakan-merdeka-belajar-kampus-merdeka/, diakses tanggal 18 Desember.

Fitriani Ahlan Sjarif, (2017) Gaya Perumusan Kalimat Perintah Pembentukan Peraturan Yang Menjalankan Delegasi Dari Undang-Undang Di Indonesia, Pakuan Law Review Volume 3, Nomor 2, Juli-Desember. Retrieved from https://doi.org/10.33751/palar.v3i2.396

Henny Nuraeny \& Tanti Kirana Utami, (2015), Legal Protection Against Children Who Are Victims Of Human Trafficking In Cianjur District Studied Bu Human Prespective, Jurnla Dinamika Hukum, Vol.15 No.2. Retrieved from https://doi.org/10.20884/1.jdh.2015.15.2.344

Kemendikbud RI, Buku Pedoman IKU PTN.

Susetyo, (2020) Permasalahan Implementasi Kurikulum Merdeka Belajar Program Studi Pendidikan Bahasa Indonesia FKIP Universitas Bengkulu, Prosiding Seminar Daring Nasional: Pengembangan Kurikulum Merdeka Belajar Program Studi Pendidikan Bahasa Indonesia, 21 Oktober, Retrieved from https://ejournal.unib.ac.id/index.php/semiba/issue/view/956/

https://dikti.kemdikbud.go.id/kabar-dikti/kampus-kita/revitalisasi-kurikulumdengan-berimplementasi-mbkm/, diakses tanggal 15 Desember 2021.

https://sevima.com/merdeka-belajar-kampus-merdeka-bagaimana-penerapankurikulum-dan-ekuivalensinya/, diakses tanggal 16 Desember 2021.

https://ummetro.ac.id/perspektif-mbkm-dalam-pendidikan-tinggi/,diakses tanggal 18 Desember 2021 